\title{
APLIKASI SISTEM PAKAR DIAGNOSA PENYAKIT LAMBUNG MENGGUNAKAN FORWARD CHAINING
}

\author{
Ahmad Setiadi $^{1 *}$, Y Yunita ${ }^{2}$, Ibung Prasetio Nugroho ${ }^{3}$ \\ ${ }^{1}$ Sistem Informasi, Universitas Binasarana Informatika Kampus Karawang, Jalan Banten Nomor 1 \\ Karangpawitan Karawang Indonesia \\ ${ }^{2}$ Teknik Informatika, STMIK Nusa Mandiri Jakarta, Jalan Damai Nomor 8 Warung Jati Barat Jakarta \\ Selatan Indonesia \\ ${ }^{3}$ Sistem Informasi, STMIK Nusa Mandiri Jakarta, Jalan Damai Nomor 8 Warung Jati Barat Jakarta \\ Selatan Indonesia \\ *email: ahmad.ams@bsi.ac.id
}

\section{Received: 17 Mei 2019 Accepted: 1 Juni 2019 Published: 30 Juni 2019}

\begin{abstract}
Abstrak
Penyakit pencernaan ataupun penyakit lambung adalah penyakit yang sering dialami oleh masyarakat. Kesadaran akan kesehatan masyarakat yang masih rendah, kebiasaan hidup yang selalu ingin hidup praktis, pengetahuan masyarakat yang sedikit dari gejala awal dari suatu penyakit merupakan faktorfaktor penyebab penyakit menjadi parah ketika penderita ditangani oleh tenaga paramedis. Penelitian ini bertujuan untuk membuat sebuah aplikasi sistem pakar diagnosa penyakit lambung berbasis web. Penelitian ini mempunyai tiga tahap yaitu pertama tahap pengumpulan data dan wawancara dengan tiga dokter yang ada dipuskesmas kecamatan Grogol Petamburan. Tahap kedua adalh membuat rule sebanyak 6 rule dan menentukan gejala sebanyak 36 gejala dan tahap terakhir adalah Implementasi Sistem Pakar berbasis Web. Metode yang digunakan adalah Metode Forward Chaining dimana metode ini mempunyai cara kerja dengan memulai proses pencarian dari sekumpulan data atau fakta, dari data-data tersebut menghasilkan suatu kesimpulan.
\end{abstract}

Kata kunci: sistem pakar, penyakit lambung

\begin{abstract}
Digestive disease or gastric disease is a disease that is often experienced by people. Awareness of public health is still low, habits of life that always want to live practically, public knowledge that is a little of the initial symptoms of an illness is a factor that causes the disease to be severe when patients are treated by paramedics. This study aims to create a web-based application of an expert system for diagnosing gastric disease. This study has three stages, namely the first stage of data collection and interviews with three doctors in the community center in Grogol Petamburan sub-district. The second stage is to make the rule as much as 6 rules and determine the symptoms of 36 symptoms and the last stage is the implementation of a Web-based Expert System. The method used is the Forward Chaining Method where this method has a way of working by starting the search process from a set of data or facts, from this data to produce a conclusion.
\end{abstract}

Keywords: expert system, gastric disease

(C) 2019 LPPM IKIP PGRI Pontianak, Indonesia 


\section{PENDAHULUAN}

Kesehatan adalah hal terpenting dalam kehidupan, menjaga pola hidup sehat dapat membuat tubuh terhindar dari penyakit dan membuat sistem pencernaan yang berada di tubuh kita dapat bekerja dengan optimal, akan tetapi terkadang sebagian orang kurang memperhatikannya. Sebagai contoh penyakit lambung merupakan penyakit yang tidak bisa dianggap remeh, karena jika dibiarkan dapat mengakibatkan penyakit yang lain muncul dan bisa juga menyebabkan kematian jika tidak segera ditangani. Penyakit lambung dapat disebabkan oleh pola makan yang tidak sesuai, beban pikiran dan juga infeksi yang disebabkan oleh bakteri. Beberapa penyakit yang menyerang lambung, diantarnya adalah Gastritis Akut Erosif, Gastritis Kronis, Kolik Abdomen, Gastroesophageal Reflux Disease (GERD). Appendicitis, Karsinoma/kanker Lambung, dan Gastroenteritis (Akmal, Faza, Winarni \& Sri, 2014).

Menurut (Mardalena, 2018) penyakit lambung adalah peradangan pada lapisan lambung yang disebabkan oleh mikroorganisme, penyakit ini lebih disebabkan oleh bakteri Helycobacterpylori, selain disebabkan oleh bakteri penyakit pada lambung juga dapat diakibatkan karena pola hidup dan pola makan yang tidak teratur. Untuk meminimalkan terjadinya masalah tersebut, maka diperlukan penerapan teknologi informasi secara maksimal. Salah satu pemanfaatan teknologi tersebut adalah dengan penggunaan sistem pakar.

Menurut (Kusrini, 2013) Sistem pakar adalah aplikasi berbasis komputer yang digunakan untukmenyelesaikan masalah sebagaimana yang dipikirkan oleh pakar. Pakar yang dimaksud adalah orang yang mempunyai keahlian khusus yang dapat menyelesaikan masalah yang tidak dapat diselesaikan oleh orang awam. Dengan adanya permasalahan diatas dalam penelitian ini penulis memberikan suatu pemecahan masalah dengan pembuatan Sistem Pakar untuk Mendiagnosa Penyakit Lambung dengan menerapkan sebuah metode yaitu Metode Forward Chaining, agar pasien bisa mengetahui jenis penyakit pencernaan apa yang kemungkinan di derita yang dikarenakan oleh suatu gejala atau beberapa gejala sekaligus yang di derita pasien.

Andriani (2016) mengatakan bahwa tujuan perancangan sistem pakar adalah untuk mempermudah kerja atau bahkan mengganti tenaga ahli, penggabungan ilmu dan pengalaman dari beberapa ahli, training tenaga ahli baru, penyediaan keahlian yang baru diperlukan oleh suatu proyek yang tidak mampu membayar tenaga ahli, pada prinsipnya sistem pakar tersusun atas beberapa komponen yang mencakup pakar, fasilitas akuisisi pengetahuan, sistem berbasis pengetahuan (knowledge based system), mesin inferensi (inference engine), fasilitas untuk 
penjelasan dan justifikasi, penghubung antara pengguna dan sistem pakar (user interface), serta perbaikan pengetahuan

Sistem pakar terdiri atas dua bagian pokok, yaitu basis pengetahuan (knowledge base) dan mesin inferensi (inference engine) (Andriani, 2016). Inti dari suatu sistem pakar adalah basis pengetahuan yang merupakan representasi pengetahuan yang dimiliki oleh seorang pakar yang tersusun oleh atas fakta dan kaidah. Fakta merupakan informasi tentang objek, peristiwa, dan situasi. Sedangkan kaidah merupakan suatu cara untuk memunculkan fakta baru berdasarkan fakta yang sudah ada dan sudah diketahui. Basis pengetahuan bias kita dapatkan langsung dari seorang pakar maupun dari data histori yang berisi data data pengetahuan dari seorang pakar.

Mesin inferensi merupakan otak dari sistem pakar yang berfungsi untuk memandu proses penalaran terhadap suatu kondisi berdasarkan pada basis pengetahuan yang tersedia. Di dalam mesin inferensi terjadi proses untuk memanipulasi dan mengarahkan kaidah, model, dan fakta yang disimpan dalam basis pengetahuan dalam rangka mencapai solusi atau kesimpulan. Terdapat dua penalaran yang dapat dilakukan dalam melakukan inferensi, yaitu forward chaining dan backward chaining.

Forward chaining seperti yang terlihat pada Gambar 1. merupakan cara penalaran dengan memulai dari fakta terlebih dahulu untuk menguji kebenaran hipotesis atau mencocokan fakta atau pernyataan dimulai dari bagian sebelah kiri dulu (IF dulu). Forward chaining merupakan grup dari multiple inferensi yang melakukan pencarian dari suatu masalah kepada solusinya. Jika klausa premis sesuai dengan situasi (bernilai TRUE), maka proses akan meng-assert konsklusi. Forward chaining cocok digunakan untuk suatu aplikasi yang menghasilkan tree yang lebar dan tidak dalam.

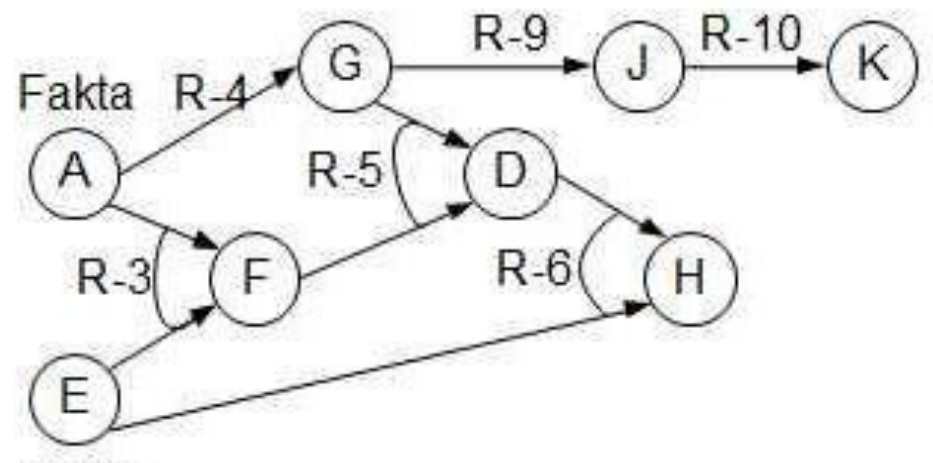

Fakta

Gambar 1. Forward chaining (Andriani, 2016) 
Backward chaining seperti yang terlihat pada Gambar 2. merupakan cara penalaran dengan memulai daru hipotesis (ekspektasi apa yang diinginkan terjadi) terlebih dahulu, dan untuk menguji kebenaran hipotesis tersebut harus dicari fakta-fakta yang ada dalam basis pengetahuan. Backward chaining juga merupakan penalaran dengan mencocokan fakta atau pernyataan yang dimulai dari bagian sebelah kanan (THEN dulu). Backward chaining cocok digunakan untuk suatu aplikasi yang menghasilkan tree yang sempit dan cukup dalam.

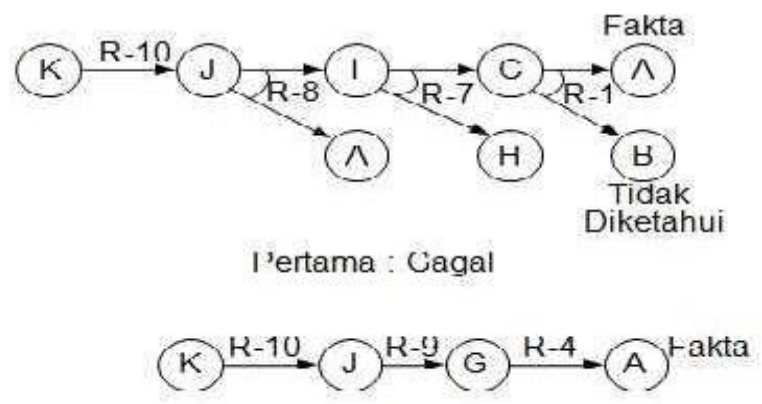

Kedua: Sukses

Gambar 2. Backward chaining (Andriani, 2016)

\section{METODE}

Penelitian ini merupakan penelitian survey dengan metode pengumpul data berupa observasi, wawancara dan studi literatur. Pelaku atau user yang menggunakan sistem ini adalah dokter yang memiliki kepakaran dalam penyakit lambung dan masyarakat sebagai pengguna atau user.

\section{HASIL DAN PEMBAHASAN}

Rancangan algoritma penyakit lambing dapat dilihat pada Gambar 3. dan tabel pakar disajikan pada Tabel 1. 


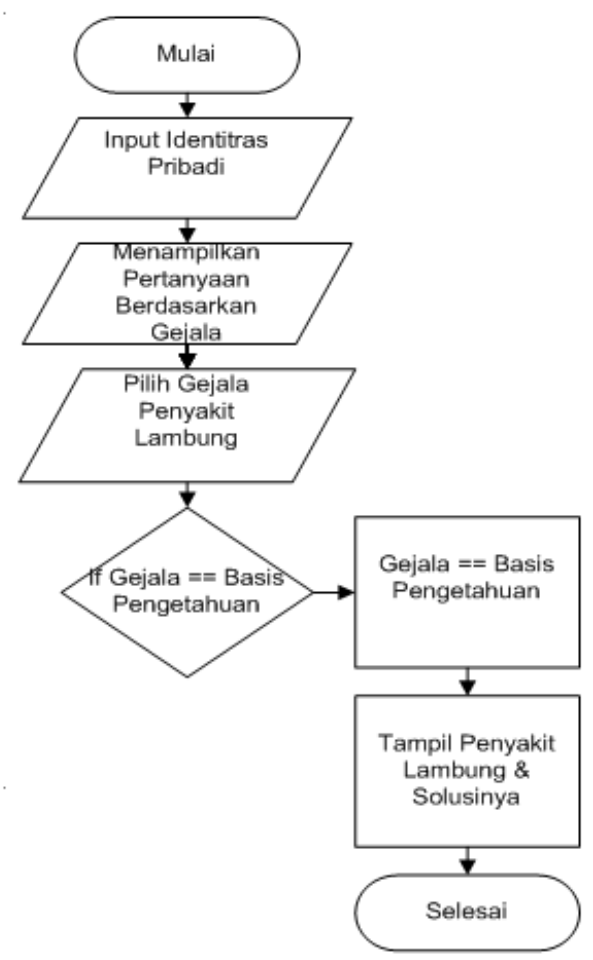

Gambar 3. Rancangan Algoritma Penyakit Lambung

Tabel 1. Tabel Pakar

\begin{tabular}{|c|c|c|c|c|c|c|}
\hline RULE & GERD & $\begin{array}{l}\text { Kolik } \\
\text { Abdomen }\end{array}$ & $\begin{array}{l}\text { Kanker } \\
\text { Lambung }\end{array}$ & Appendicitis & Gastritis & Gastroenteritis \\
\hline G001 & & $\sqrt{ }$ & $\sqrt{ }$ & $\sqrt{ }$ & & $\sqrt{ }$ \\
\hline G002 & $\sqrt{ }$ & & $\sqrt{ }$ & & $\sqrt{ }$ & \\
\hline G003 & & $\sqrt{ }$ & & $\sqrt{ }$ & & $\sqrt{ }$ \\
\hline G004 & $\sqrt{ }$ & & $\sqrt{ }$ & & $\sqrt{ }$ & $\sqrt{ }$ \\
\hline G005 & & & & $\sqrt{ }$ & & $\sqrt{ }$ \\
\hline G006 & & & $\sqrt{ }$ & $\sqrt{ }$ & $\sqrt{ }$ & \\
\hline G007 & $\sqrt{ }$ & $\sqrt{ }$ & $\sqrt{ }$ & $\sqrt{ }$ & & \\
\hline G008 & & & & & & \\
\hline G009 & & & $\sqrt{ }$ & & & \\
\hline G010 & & $\sqrt{ }$ & & & & \\
\hline G011 & $\sqrt{ }$ & & $\sqrt{ }$ & & & \\
\hline G012 & & & $\sqrt{ }$ & & $\sqrt{ }$ & \\
\hline G013 & & & $\sqrt{ }$ & $\sqrt{ }$ & $\sqrt{ }$ & $\sqrt{ }$ \\
\hline G014 & & & & $\sqrt{ }$ & $\sqrt{ }$ & $\sqrt{ }$ \\
\hline G015 & $\sqrt{ }$ & $\sqrt{ }$ & & & & \\
\hline G016 & & $\sqrt{ }$ & & & & $\sqrt{ }$ \\
\hline G017 & & & $\sqrt{ }$ & & & $\sqrt{ }$ \\
\hline G018 & $\sqrt{ }$ & & $\sqrt{ }$ & & & \\
\hline G019 & & $\sqrt{ }$ & $\sqrt{ }$ & & $\sqrt{ }$ & \\
\hline G020 & $\sqrt{ }$ & & $\sqrt{ }$ & & & \\
\hline
\end{tabular}




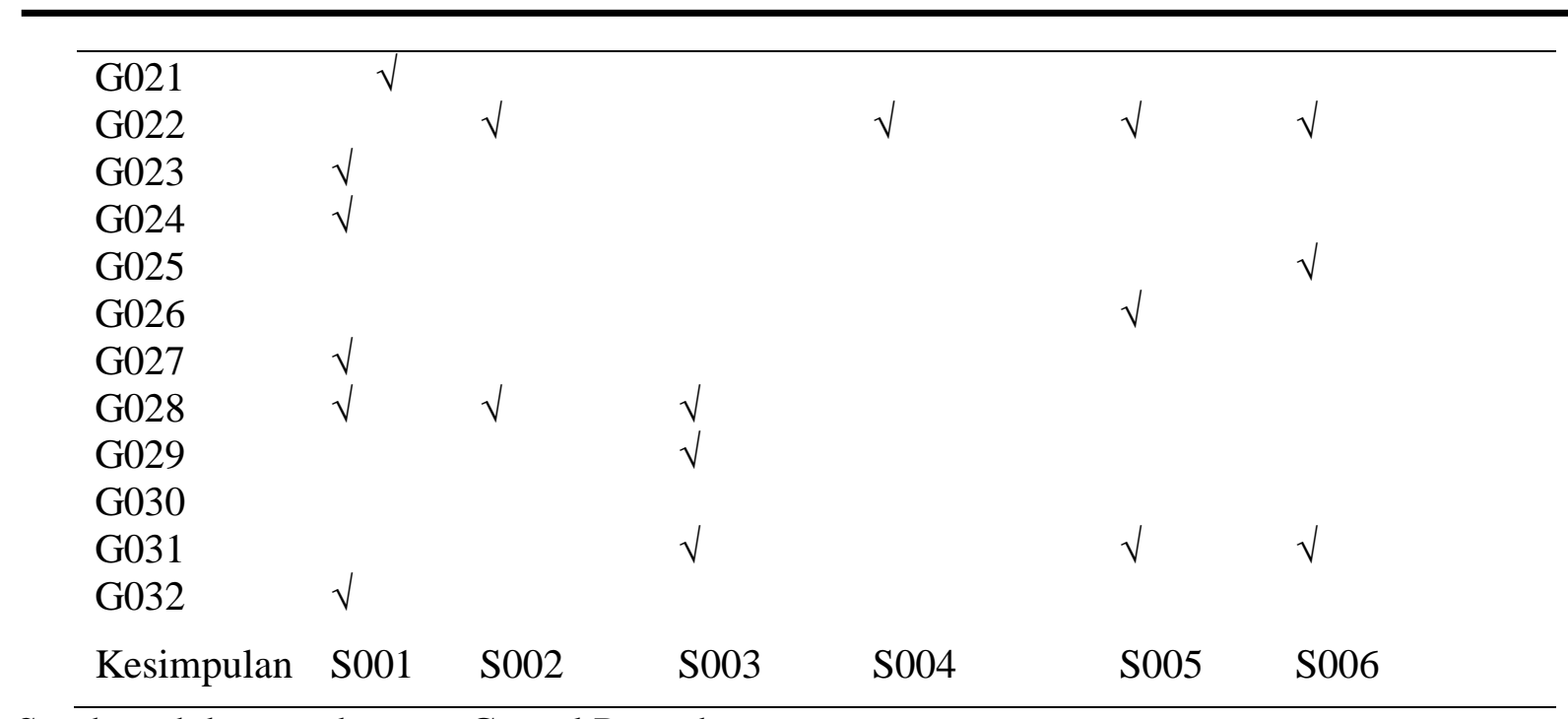

Sumber: dokter puskesmas Grogol Petamburan

Berdasarkan Tabel 1. Kolom pertama menerangkan Rule macam-macam penyakit lambung. Baris pertama menunjukkan macam-macam gejala dari penyakit. Tanda ceklist merupakan gejala apa saja yang ada pada penyakit tersebut. Sedangkan kolom kesimpulan menjelaskan solusi dari penyakit yang dihasilkan dari gejala.

\section{Rule pada sistem pakar}

Rule 1 : Jika Anda Mengalami Kembung dan demam dan mual dan kesulitan menelan dan rasa perih pada perut dan nyeri dada dan sesak nafas dan sakit tenggorokan dan lidah seperti berlapis lendir dan Bau Nafas Tidak Sedap dan Mulut Terasa Pahit dan Muntah Darah dan suara serak Maka anda di diagnosa mengalami penyakit GERD.

Rule 2 : Jika Anda Mengalami Mules dan sendawa berlebih dan mual dan susah buang air besar dan rasa perih pada perut dan BAB berdarah dan Tinja Berwarna Gelap dan muntah dan Muntah darah Maka Anda di diagnosa mengalami penyakit Kolik Abdomen.

Rule 3 : Jika Anda mengalami mules dan kembung dan demam dan Pembengkakan di area perut dan mual dan Penurunan Berat Badan dan Kesulitan Menelan dan Cepat Kenyang dan Kehilangan Nafsu Makan dan Badan Cepat Lelah dan nyeri dada dan Tinja Berwarna Gelap dan sesak nafas dan muntah dan muntah darah dan Sakit Perut Bagian Atas(Ulu Hati) dan tubuh terasa lemah Maka Anda di diagnosa mengalami penyakit Kanker Lambung.

Rule 4 : Jika Anda mengalami mules dan sendawa berlebih dan diare dan Pembengkakan di 
area perut dan mual dan Kehilangan Nafsu Makan dan nyeri perut dan muntah Maka Anda di diagnosa mengalami penyakit Appendicitis

Rule 5: Jika Anda mengalami kembung dan demam dan mual dan Cepat Kenyang dan Kehilangan Nafsu Makan dan nyeri perut dan Tinja Berwarna Gelap dan muntah dan Radang Lambung dan cegukan Maka Anda di diagnosa mengalami penyakit Gastritis.

Rule 6: Jika Anda mengalami mules dan Sendawa Berlebih dan demam dan diare dan mual dan sakit kepala dan Penurunan Berat Badan dan Kehilangan Nafsu Makan dan nyeri perut dan $\mathrm{BAB}$ Berdarah dan Badan Cepat Lelah dan muntah dan kram perut dan tubuh terasa lemah Maka Anda di diagnosa mengalami penyakit Gastroenteritis.

Pohon pakar keputusan dapat dilihat pada Gambar 4.

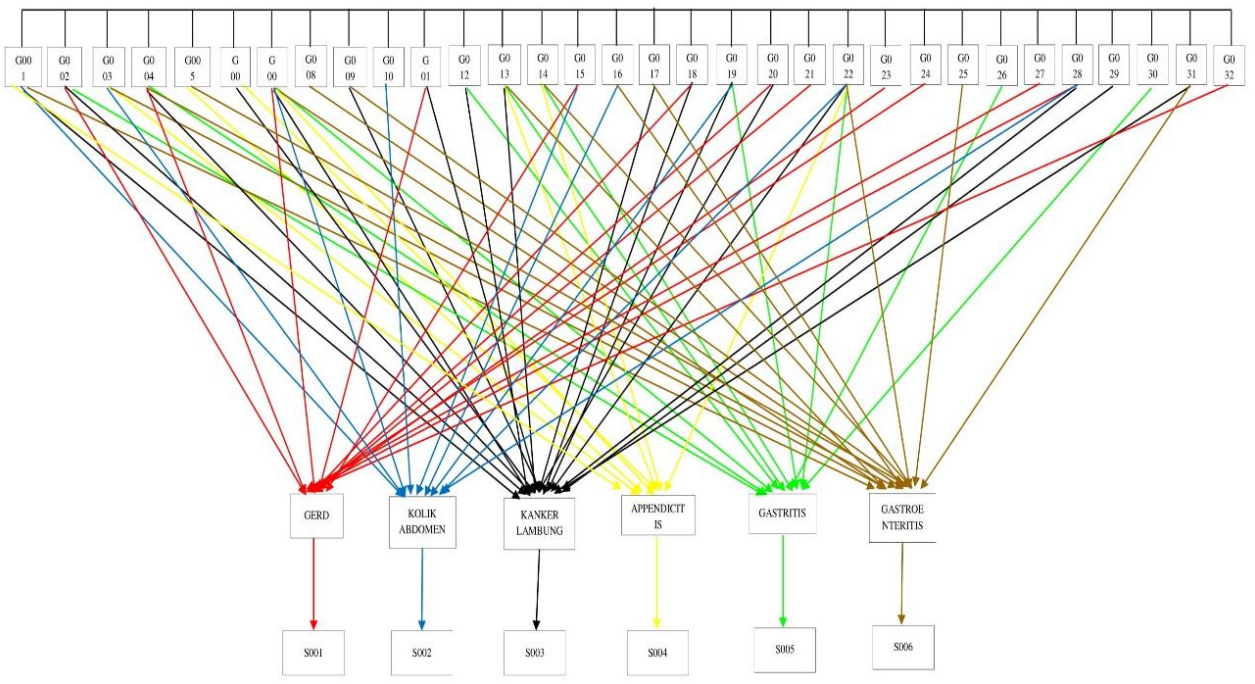

Gambar 4. Pohon Akar Keputusan

Keterangan gejala dapat dilihat pada Tabel 2 dan keterangan Rule dapat dilihat pada Tabel 3.

Tabel 2. Keterangan Gejala

\begin{tabular}{lll}
\hline G001: Mules & G011: Kesulitan menelan & G021: Sakit Tenggorokan \\
G002: Kembung & G012: Cepat kenyang & G022: Muntah \\
G003: $\quad$ Sendawa & G013: Kehilangan nafsu & G023: Lidah Seperti Berlapis \\
Berlebih & makan & Lendir \\
G004: Demam & G014: Nyeri perut & G024: Bau Nafas Tidak Sedap \\
G005: Diare & G015: Rasa perih pada & G025: Kram Perut \\
& perut & \\
\hline
\end{tabular}


G006: Pembengkakan G016: BAB Berdarah di area perut

G007: Mual

G008: Sakit Kepala

G009: Penurunan Berat

Badan

G010: Susah BAB

G031: Tubuh Terasa

Lemah

G018: Nyeri dada

G020: Sesak Nafas

G032: Suara Serak
G026: Radang Lambung

G027: Mulut Terasa Pahit

G028: Muntah Darah

G029: Sakit Perut Bagian

Atas (Ulu Hati)

G030: Cegukan

Tabel 3. Keterangan Rule

\begin{tabular}{ll}
\hline S001 : GERD & S004 : Appendicitis \\
S002 : Kolik Abdomen & S005 : Gastritis \\
S003 : KankerLambung & S006 :Gastroenteritis
\end{tabular}

Keterangan solusi adalah sebagai berikut:

S001: Merubah Pola Hidup Menjadi Lebih Sehat, Berhenti Merokok, Hindari Berbaring setelah Makan, Hindari makan dengan jumlah Porsi yang besar, Hindari Obesitas, Hindari stress, istirahat cukup, olahraga teratur, dan Segera datang ke Puskesmas atau Klinik Terdekat untuk mendapatkan penanganan medis jika mengalami sakit GERD. Pengobatan: antasida, PPI (Proton Pump Inhibitor) seperti, omeprazol, lansoprazol, dan Penghambat reseptor $\mathrm{H} 2$ seperti Ranitidin, dan prokinetik seperti domperidon

S002: Tidur dan istirahat cukup, makan makanan bergizi, minum air dalam jumlah cukup, olahraga rutin, menghindari rokok dan alkohol, dan bila nyeri dapat diberikan obat anti nyeri dan mengompres perut dengan air hangat. Pengobatan: koreksi dehidrasi, beri obat nyeri (Asam Mefenamat), bila tidak membaik, Segera Konsultasi ke Puskesmas atau Klinik terdekat untuk dirujuk ke Rumah Sakit.

S003: Rajin Berolahraga, Perbanyak minum air putih, Perbanyak konsumsi buah dan sayur, Jangan merokok, Hindari mengkonsumsi makanan yang di awetkan, Hindari makan daging yang di goreng dan dibakar, dan Segera Ke Klinik atau Puskesmas terdekat untuk mendapatkan penanganan medis jika mengalami sakit kanker lambung. Pengobatan: Radioterapi, Kemoterapi, dan Operasi. 
S004: konsumsi makanan berserat, jangan tunda buang air besar (BAB), batasi asupan kafein dan alkohol, banyak konsumsi air putih, kurangi makan pedas, santan dan berlemak, hindari stress, olahraga teratur, dan Segera datang ke Puskesmas atau Klinik terdekat untuk mendapatkan penanganan lebih lanjut. pengobatan : pemberian antibiotik seperti metronidazole dan ciprofloxacin, pemberian obat imunosupresan seperti azathioprine, cyclosporine, dan infliximab, dan pemberian OAINS seperti kortikosteroid.

S005: Mengganti Kebiasaan Makan, Menghindari minuman beralkohol, Hindari makanan pedas dan asam dan mengandung gas, Kurangi atau hindari konsumsi kopi, teh, dan minuman bersoda, Usahakan jadwal makan teratur dan jangan sampai terlambat, Kelola stres dengan baik melalui olahraga, metode relaksasi atau kegiatan lain yang disukai, dan Segera Konsultasi ke Klinik atau Puskesmas Terdekat untuk mendapatkan penanganan medis. Pengobatan : Obat Antasida Doen, Obat Ranitidin, Omeprazole, dan Promag.

S006: Mencuci tangan dengan air mengalir dan sabun setiap kali sebelum makan, Memilih makanan yang higienis untuk dikonsumsi, Gunakan tisue untuk mengeringkan tangan, Pastikan Makanan yang dimasak sudah matang, Bersihkan kamar mandi dan toilet secara teratur, Banyak Minum air Putih, Banyak Istirahat, Hindari susu, alkohol dan kafein, dan Konsultasikan Ke Klinik atau Puskesmas terdekat untuk mendapatkan penanganan medis secara lebih lanjut. Pengobatan : oralit, obat anti diare seperti loperamide.

\section{Analisa Kebutuhan Software}

Berikut ini adalah spesifikasi kebutuhan dari sistem pakar diagnose penyakit lambung dengan metode forward chaining.

A1. Pengunjung dapat memilih menu konsultasi agar dapat melakukan konsultasi kesehatan untuk mengetahui penyakit yang diderita dan melihat solusi untuk upaya pencegahan.

A2. Pengunjung dapat memilih menu artikel kesehatan untuk melihat informasi tentang penyakit pada lambung.

A3. Pengunjung dapat memilih menu buku tamu untuk bertanya tanya tentang penyakit lambung dan ingin memberikan kritik atau saran pada website.

A4. Pengunjung dapat memilih menu profil untuk melihat sejarah berdirinya puskesmas kecamatan grogol petamburan. 
A5. Pengunjung dapat memilih menu kontak kami untuk melihat alamat, nomer telfon dan email puskesmas kecamatan grogol petamburan.

Halaman Administrasi:

B1. Admin dapat melakukan login sesuai dengan hak akses.

B2. Admin dapat mengelola data artikel.

B3. Admin dapat mengelola data gejala

B4. Admin dapat mengelola data solusi.

B5. Admin dapat mengola data rule

B6. Admin dapat mengelola data buku tamu

B7. Admin dapat mengelola data user.

B8. Admin dapat melihat laporan diagnose, data gejala dan laporan data solusi.

\section{UML (Unifield Modeling Language)}

Menurut Rosa \& Shalahuddin (2016) UML (Unifield Modeling Langueage) adalah "Salah satu standar bahasa yang banyak digunakan di dunia industri untuk mendefinisiskan requirement, membuat analisis \& desain, serta mengambarkan arsitektur dalam pemrograman berorientasi objek". Use Case Diagram dalam sistem pakar penyakit lambung dengan metode forward chaining adalah use diagram halaman pengunjung seperti pada Gambar 5 dan use diagram halam admin seperti pada Gambar 6.

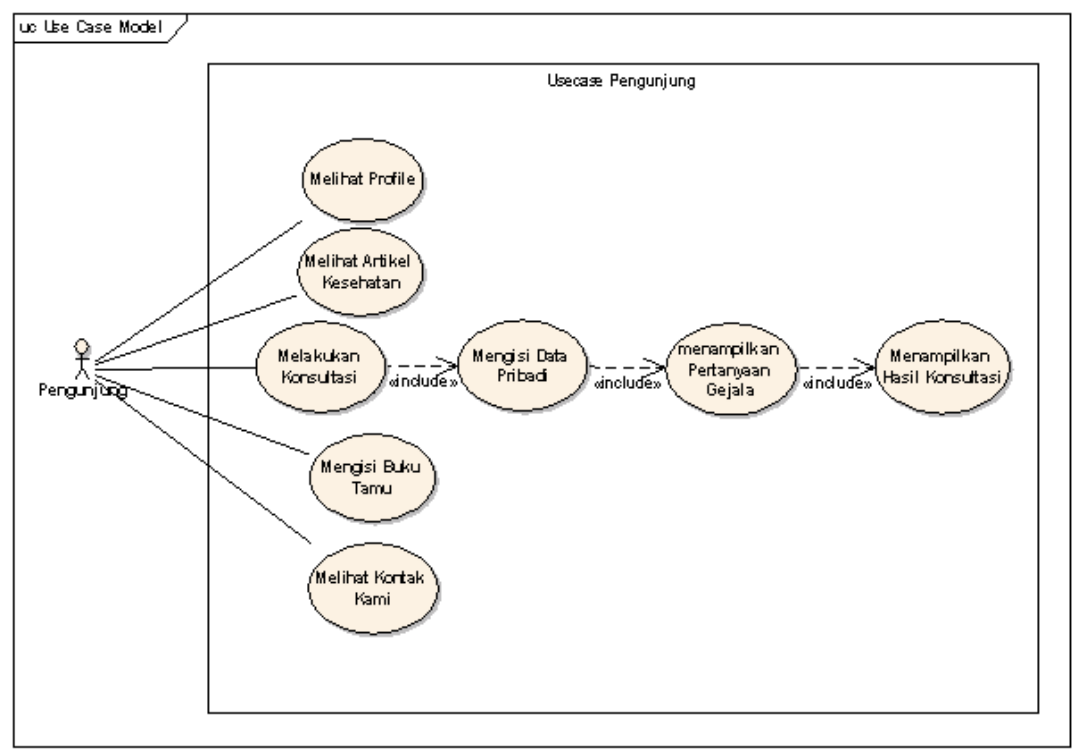

Gambar 5. Use diagram halaman pengunjung 


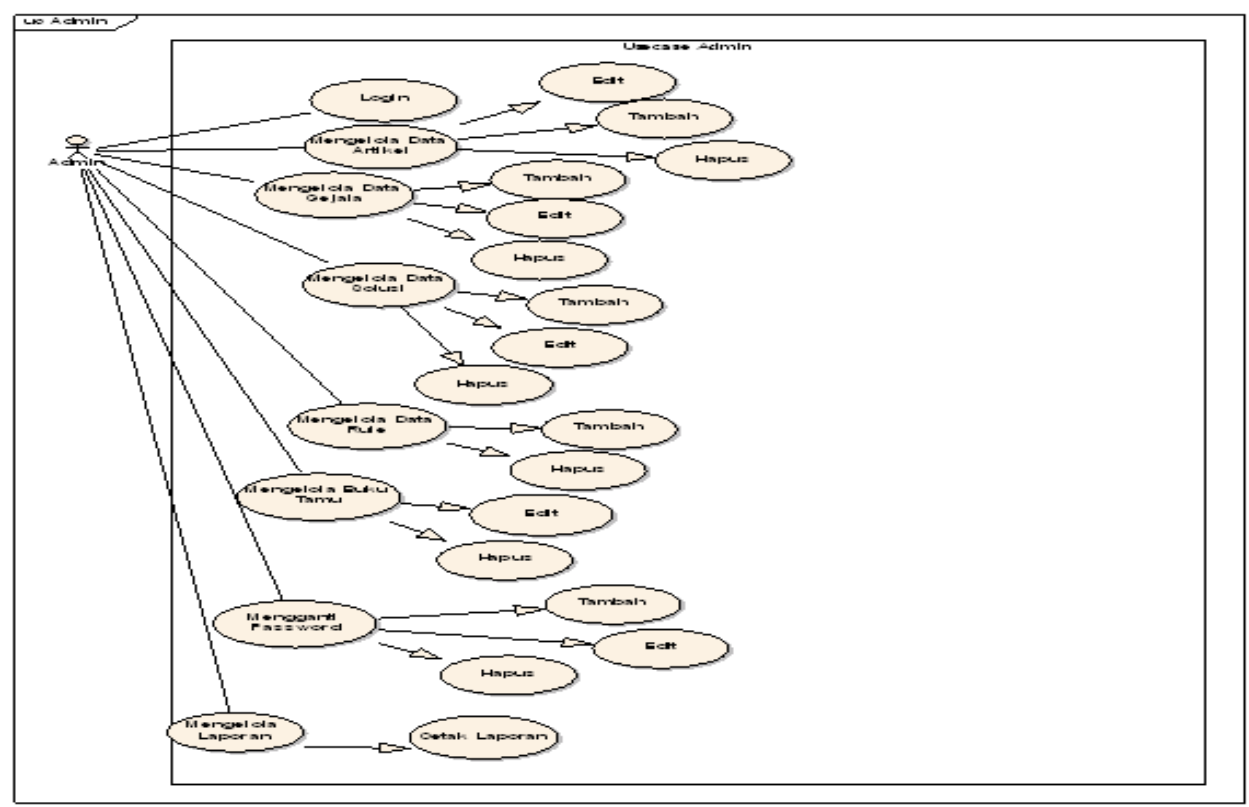

Gambar 6. Use diagram halaman admin

Desain database

\section{ERD (Entiy Relationship Diagram)}

Menurut (Fathansyah, 2015) Model Entity Relationship yang berisi komponen-komponen Himpunan Entitas dan Himpunan Relasi yang masing-masing dilengkapi dengan atribut-atribut yang mempresentasikan seluruh fakta dari 'dunia nyata' yang ditinjau, dapat digambarkan dengan menggunakan diagram Entity-Relationship (Diagram E-R). Bentuk ERD (Entity Relationship Diagram ) yang menggambarkan model basis data dari sistem yang dibuat disajikan pada Gambar 7.

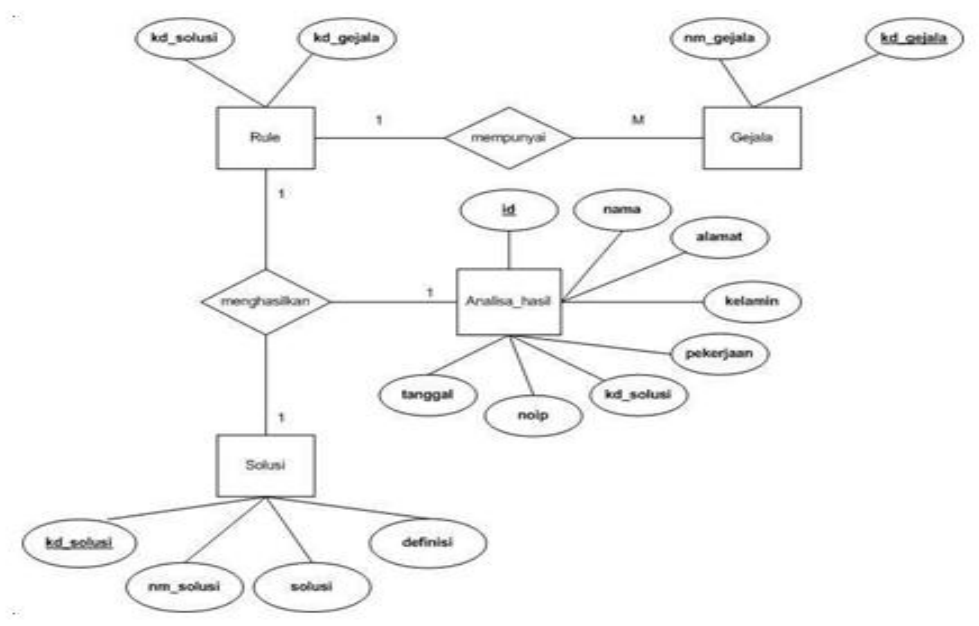

Gambar 7. Entity Relationship Diagram 


\section{User Interface}

Tampilan pengunjung dapat dilihat pada Gambar 8 dan tampilan halaman konsultasi kesehatan dapat dilihat pada Gambar 9.

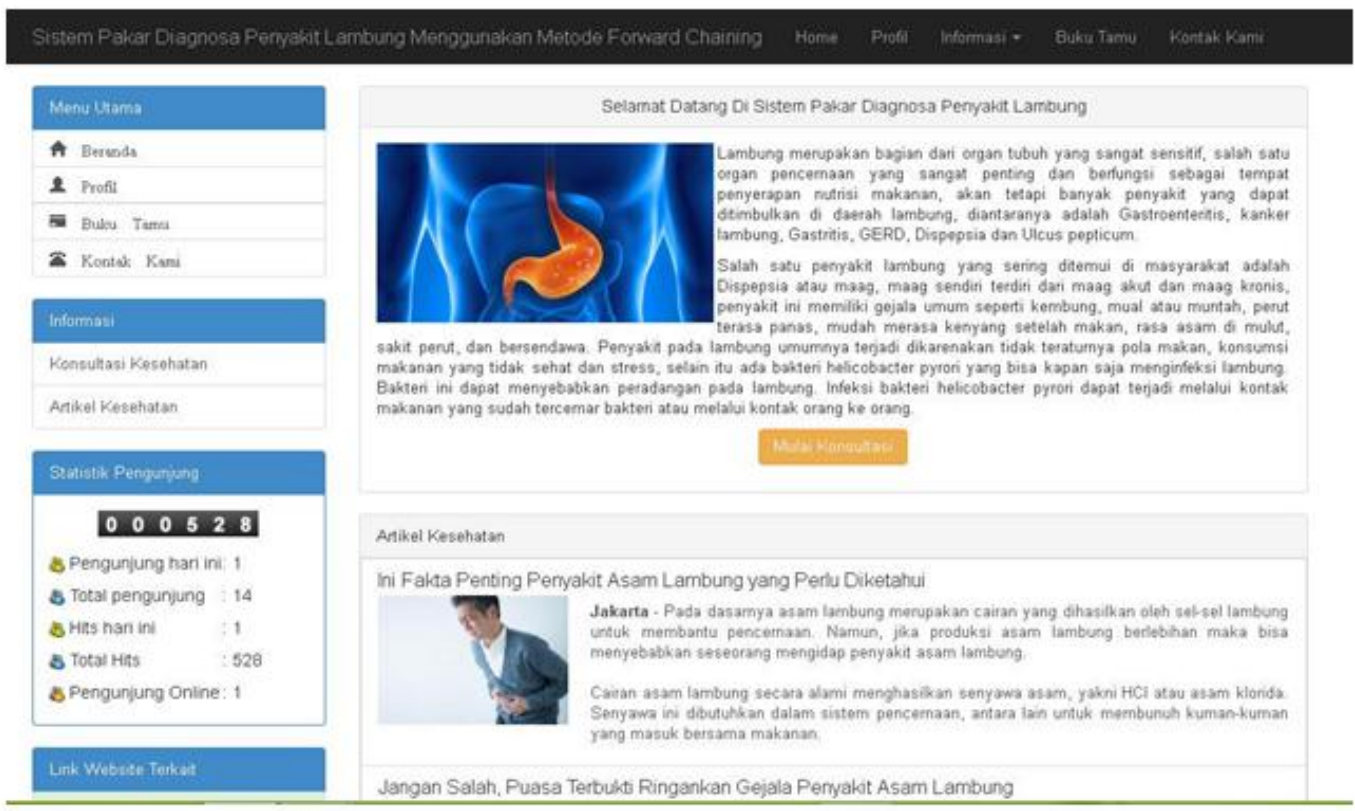

Gambar 8. Tampilan Halaman Pengunjung

localhost/pakar_ambung/pagenconsultation

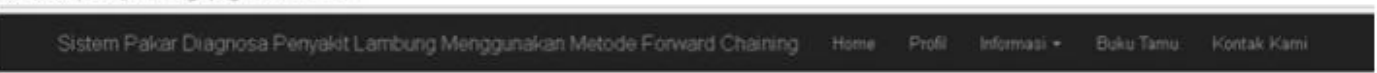

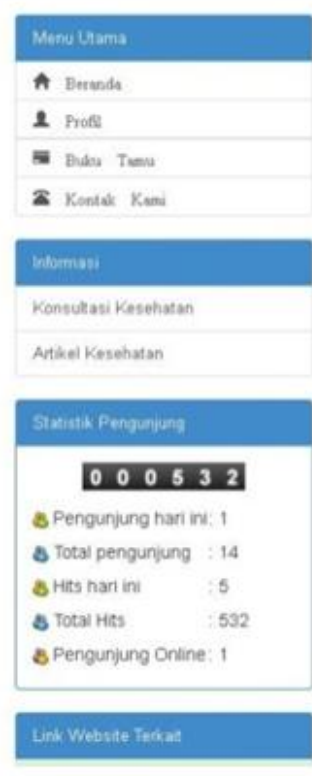

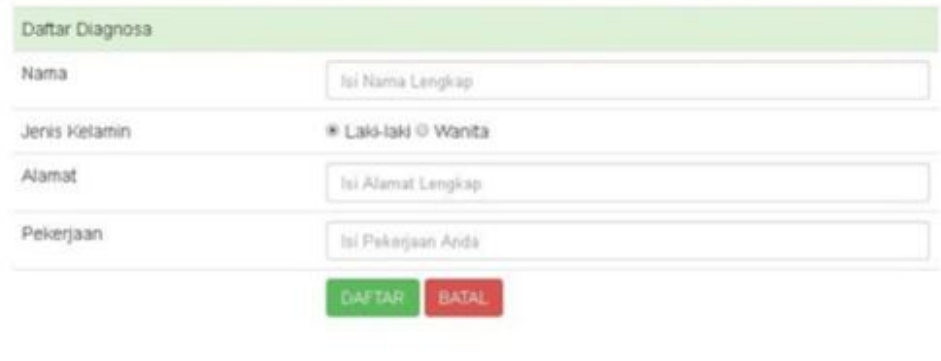

Gambar 9. Tampilan Halaman Konsultasi Kesehatan 


\section{SIMPULAN}

Berdasarkan pada pembahasan yang telah diuraikan, maka penulis menyimpulkan dengan adanya sistem pakar diagnosa penyakit lambung dengan metode forward chaining ini, maka dapat membantu masyarakat untuk mengetahui gejala dan pengetahuan mengenai penyakit lambung berdasarkan gejala-gejala yang dialami tanpa harus datang kepuskesmas. Sistem pakar diagnosa penyakit lambung ini membantu para pakar dalam menangani pasien yang mengalami gejala penyakit lambung dan cara pengobatan dansolusinya

\section{DAFTAR PUSTAKA}

Andriani, A. (2016). Pemrograman sistem pakar. in mediakom (cetakan pe, p. 14). Yogyakarta: mediakom. Retrieved from www.mediakom-penerbit.com

Fathansyah.(2015). Basis data revisi kedua. Bandung:Informatika Bandung.

Kusrini.(2013). Sistem pendukung keputusan. Yogyakarta: In Andi Offset (p. 4).

Mardalena, I. (2018). Asuhan keperawatan pasien dengan gangguan sistem pencernaan. In Pustaka Baru Press (p. 57).

Akmal, Faza, Winarni \& Sri (2014). Sstem pakar untuk mendiagnosa penyakit lambung dengan implementasi metode cbr (case-based reasoning) berbasis web. Jurnal sarjana teknik informatika, 2(1). 